PontIFícIA UNIVERSIDADE CATÓLICA DO RIO DE JANEIRO

\title{
Análise do modelo de gestão de pessoas em agências de varejo do banco Itaú Unibanco
}

Adriano da Silva Sobrinho

Trabalho de Conclusão de Curso

Centro de ciências socials - CCS

DEPARTAMENTO de AdMINISTRAÇÃo

Graduação em Administração de Empresas

Rio de Janeiro, novembro de 2018. 


\section{Adriano da Silva Sobrinho}

\section{Análise do modelo de gestão de pessoas em agências de varejo do banco Itaú Unibanco}

\section{Trabalho de Conclusão de Curso}

Trabalho de Conclusão de Curso, apresentado ao programa de graduação em Administração da PUC-Rio como requisito parcial para a obtenção do título de graduação em Administração.

Orientador (a): Marcelo Pineiro

Rio de Janeiro

Novembro de 2018. 


\section{Agradecimentos}

Primeiramente a Deus, que por mais que eu não possa vê-lo sei que sempre está presente em todos os momentos e nunca me deixou desistir durante toda a caminhada da graduação.

À minha mãe, Dona Maria Dalva e meu padrasto querido, seu Simão, que estiveram comigo em diversos momentos difíceis e muitos outros alegres, graças a Deus.

Aos meus tios de consideração, Marinete e Luís Carlos, que me apoiaram e me criaram junto a seus próprios filhos, investindo em meu futuro dando espaço para que eu tivesse oportunidades de vida muito melhores. Essa vitória também é de vocês.

Em especial agradeço a minha noiva Vanessa, que realizou e ainda realizará muitos sonhos ao meu lado, como nossa casa e nossa história que cada vez mais cresce e se fortifica. Ao seu lado sempre pude tudo, e por isso a amo.

Aproveito ainda para citar um grande gestor que passou pela minha vida profissional e contribuiu bastante para meu crescimento, e hoje é um grande amigo, Thiago Fernandes.

Por fim, mas não menos importante agradeço a oportunidade te ter tido grandes mestres no decorrer de todo o curso, principalmente ao meu orientador Marcelo Piñeiro por toda a paciência comigo, principalmente nessa reta final em me acolher como orientando e me impulsionar para a construção de uma monografia de qualidade.

Estou muito feliz por concluir mais essa etapa.

"Se você pode sonhar, você pode fazer"

Walt Disney 


\section{Resumo}

Sobrinho, Adriano. Análise da eficiência do modelo de gestão bancária do banco Itaú Unibanco. Rio de Janeiro, 2018. 52 p. Trabalho de Conclusão de Curso - Departamento de Administração. Pontifícia Universidade Católica do Rio de Janeiro.

O presente estudo tem como objetivo mapear e listar as características do modelo de gestão bancário praticada no banco Itaú Unibanco, levantando hipóteses através de teorias conhecidas sobre gestão de pessoas e a visão dos gestores acerca do que entendem e exercem em sua liderança e cruzando com a percepção de seus colaboradores subordinados acerca do que for apurado para então validar a eficiência do modelo identificado, apontando assim pontos fortes e pontos a serem desenvolvidos pelos líderes que trabalham na organização.

Palavras-chave:

Banco, Itaú Unibanco, gestão bancária, gestão de pessoas, liderança. 


\section{Abstract}

Sobrinho, Adriano. Analysis of the efficiency of the bank's management model of the bank Itaú Unibanco. Rio de Janeiro, 2018. 52 pages. Undergraduate Thesis - Department of Administration. Pontifical Catholic University of Rio de Janeiro.

The present study aims to map and list the characteristics of the bank management model practiced at the Itaú Unibanco bank, raising hypotheses through known theories about people management and the managers view of what they understand and exert in their leadership and crossing with the perception of its subordinate employees about what has been verified and then validate the efficiency of the identified model, thus pointing out strengths and points to be developed by the leaders working in the organization.

Key-words:

Bank, Itaú Unibanco, bank management, people management, leadership. 


\section{Sumário}

1 O Tema e o Problema de Estudo 9

1.1. Introdução ao Tema e ao Problema de Estudo 9

1.2. Objetivo Final 12

1.3. Objetivos Intermediários 12

1.4. Delimitação do Estudo 12

1.5. Relevância do Estudo 12

2. Referencial Teórico 14

2.1. Gestão Bancária 14

2.2. Gerenciamento Pelas Diretrizes 15

2.3. Modelo de Gestão Itaú Unibanco Erro! Indicador não definido.

2.4. Modelo de Gestão Por Competências Erro! Indicador não definido.

2.5. Administração no Brasil 17

2.5.1. Traços Culturais da Administração Brasileira 17

$\begin{array}{ll}\text { 2.6. Cultura Organizacional } & 19\end{array}$

$\begin{array}{ll}\text { 2.7. Liderança } & 19\end{array}$

2.8. Liderança Transacional e Transformacional 20

2.9. Motivação Humana 21

2.9.1. Hierarquia das Necessidades de Maslow 22

2.9.2. Teoria dos Dois Fatores de Herzberg 22

2.10. Gestão de Conhecimento 23

2.11. Meritocracia 24

2.12. Modelo Atual de Empresa de Sucesso 25

3 . Métodos e Procedimentos de Coleta e de Análise de Dados do Estudo27

3.1. Etapas de Coleta de Dados 27

3.2. Fontes de Informação Selecionadas Para Coleta de Dados 28

3.3. Procedimentos e Instrumentos de Coleta de Dados Utilizados no $\begin{array}{ll}\text { Estudo } & 28\end{array}$

3.4. Formas de Tratamento e Análise do Dados Coletados para o Estudo28

3.5. Limitações do Estudo 29 
4. Apresentação e Análise dos Resultados 30

4.1. A Empresa 30

4.2. Modelo de Gestão de Pessoas Itaú Unibanco 30

4.3. Perfil dos Entrevistados 31

4.4. Resultado das Entrevistas com Gestores 32

4.5. Resultado do Questionário com Demais Colaboradores 36

4.5.1. Liderança 36

$\begin{array}{ll}\text { 4.5.2. Motivação } & 37\end{array}$

4.5.3. Espírito de equipe 39

$\begin{array}{ll}\text { 4.5.4. Meritocracia } & 40\end{array}$

5. Conclusão 42

5.1. Sugestões e recomendações para novos estudos 43

6. Referências Bibliográficas 44

7. Anexos 46

7.1. Formulário entrevista com gestores 46

$\begin{array}{ll}\text { 7.2. Formulário entrevista com colaboradores } & 47\end{array}$

\section{Sumário de Gráficos}

Table 1 - Afirmações acerca de Liderança............................................. 37

Table 2 - Afirmações acerca da Motivação ............................................ 38

Table 3 - Afirmações acerca do Espírito em equipe............................... 39

Table 4 - Afirmações acerca da Meritocracia .................................... 40 


\section{Sumário de Figuras}

Figure 1 - O estilo brasileiro de administrar segundo Barros e Prates ..... 18

Figure 2 - Teorias sobre liderança segundo Chiavenato........................ 20

Figure 3 - A hierarquia das necessidades humanas e os meios de satisfação ...................................................................... 22

Figure 4 - Diretrizes do Nosso Jeito de Fazer do Itaú Unibanco .............. 31 


\section{Tema e o Problema de Estudo}

Este tópico explicitará o tema que se pretende desenvolver e seu respectivo problema de estudo, apresentando os antecedentes que justificaram o autor a pesquisar a respeito do tema. Posteriormente declarando sua delimitação da pesquisa e relevância do estudo.

\subsection{Introdução ao Tema e ao Problema de Estudo}

Estudos como os de Maciel e Costa, de outubro de 2014, dissertam que o impulso institucional à reorganização do setor financeiro na década de 1990 no Brasil aprofundou os ajustes internos e sua por meio de um intenso processo de automação e de subcontratação de atividades (contabilidade, compensação, expedição, custódia etc.). A força de trabalho empregada foi drasticamente reduzida: entre 1993 e 1999 mais de 200 mil postos de trabalho, entre diretores, gerentes, técnicos, caixas e escriturários, foram eliminados. Segundo Maciel e Costa (2014) dados do Ministério do Trabalho contabilizam uma perda de $44 \%$ no nível de emprego do setor entre 1990 e 2005. Os 750 mil trabalhadores empregados em 1990 foram reduzidos para um contingente de apenas 450 mil em 2005. Mas as mudanças não se restringiram ao forte enxugamento dos quadros, elas redimensionaram as estratégias na oferta de produtos e serviços, que, aliadas ao uso intensivo da informática, provocaram alterações no trabalho bancário, assim como nas políticas de gestão. A eliminação de tarefas duplicadas, a simplificação de procedimentos, a reorganização funcional, privilegiando a polivalência, foram processos marcantes da transformação da atividade bancária. As funções de escriturário, por exemplo, foram mescladas com outras funções (supervisão, caixa, vendedores de produtos financeiros) e os cargos de supervisão foram reduzidos, o que aponta para uma horizontalização hierárquica no setor. 
A redução dos postos de trabalho, receita da empresa enxuta, resulta numa sobrecarga de trabalho para os que permanecem. Os empregados são pressionados a intensificar seus ritmos de trabalho e, muitas vezes, estender as jornadas para darem conta dos serviços e das metas de produtividade.

Ainda segundo Maciel e Costa (2014), a automação torna o controle sobre o trabalho mais rigoroso (por exemplo, sobre o número de autenticações realizadas por dia), e ela vem atrelada a uma política de recursos humanos mais agressiva, que busca motivar o trabalhador por meio de incentivos financeiros e distinções de status. No âmbito mais subjetivo, passou-se a exigir do trabalhador maior comprometimento, cooperação, maior através de processos seletivos e avaliações de desempenho individuais. Ganha relevo a filosofia da gestão por competência. São conhecimentos, habilidades e atitudes do trabalhador que devem ser mobilizados e personificados no interesse da empresa, sob a bandeira da adaptação e da flexibilidade. Por essa lógica, os bancários são bastante pressionados a cumprirem metas de produtividade e dependem do alcance dessas metas para garantirem a renda mínima adequada à manutenção de seu padrão de vida. Tais pressões induzem a comportamentos competitivos (entre os indivíduos e entre as próprias agências) e quebram a solidariedade, os laços de amizade de longo prazo e a capacidade de resistência. Os bancos encontram na lógica da competição o mecanismo central de expropriação de excedente capacidade e disponibilidade para receber responsabilidades e, sobretudo, espírito empreendedor; requisitos esses que são cobrados.

Apesar disso, o banco Itaú Unibanco se sobressai em relação aos demais bancos do Brasil e América Latina, com um dos maiores lucros e aumentando cada vez mais seus ativos conforme mostra estudo publicado pela plataforma Economatica (2018), importante sistema de análise de investimentos. Na figura 1 é possível verificar o rankeamento dos principais bancos dos EUA e América Latina, e nela vemos o Itaú Unibanco liderando o mercado bancário brasileiro no terceiro trimestre de 2018. 
Figure 1 - Maiores lucros e ativos do $3^{\circ}$ tri de 2018, EUA e América Latina

\begin{tabular}{|c|c|c|c|c|c|}
\hline \multicolumn{6}{|c|}{$\begin{array}{r}\text { Maiores Lucros em US\$̧ no 3ro trimestre de } 2018 \text { entre bancos com } \\
\text { Total na América Latina e USA }\end{array}$} \\
\hline \multirow{2}{*}{ Banco } & \multirow{2}{*}{ Pais } & \multirow{2}{*}{\begin{tabular}{c|} 
Ativo Total \\
US\$ุ Bilhões
\end{tabular}} & \multicolumn{3}{|c|}{ Lucro liquido 3ro trim US\$ุ Milhões } \\
\hline & & & 2017 & 2018 & Variação \% \\
\hline Jpmorgan Chase \& Co & USA & 2.615 & 6.732 & 8.380 & 24,48 \\
\hline Bank Of America Corp & USA & 2.339 & 5.587 & 7.167 & 28,28 \\
\hline Wells Fargo \& Company & USA & 1.873 & 4.596 & 6.007 & 30,70 \\
\hline Citigroup Inc & USA & 1.925 & 4.133 & 4.622 & 11,83 \\
\hline US Bancorp & USA & 465 & 1.563 & 1.815 & 16,12 \\
\hline ItauUnibanco & Brasil & 403 & 1.918 & 1.560 & $-18,66$ \\
\hline Capital One Financial Corp & USA & 363 & 1.107 & 1.502 & 35,68 \\
\hline PNC Financial Services Group, Inc & USA & 380 & 1.114 & 1.389 & 24,69 \\
\hline Bradesco & Brasil & 320 & 910 & 1.251 & 37,44 \\
\hline Bank Of New York Mellon Corp & USA & 350 & 1.018 & 1.111 & 9,14 \\
\hline BB\&T Corp & USA & 223 & 640 & 832 & 30,00 \\
\hline Brasil & Brasil & 367 & 897 & 793 & $-11,56$ \\
\hline State Street Corp & USA & 234 & 685 & 765 & 11,68 \\
\hline Santander BR & Brasil & 192 & 567 & 759 & 33,97 \\
\hline Suntrust Banks Inc & USA & 211 & 538 & 752 & 39,78 \\
\hline Regions Financial Corp & USA & 125 & 311 & 564 & 81,35 \\
\hline M\&T Bank Corp & USA & 117 & 356 & 526 & 47,81 \\
\hline Keycorp & USA & 139 & 364 & 482 & 32,42 \\
\hline Citizens Financial Group Inc & USA & 159 & 348 & 443 & 27,30 \\
\hline Fifth Third Bancorp & USA & 142 & 1.014 & 433 & $-57,30$ \\
\hline Huntington Bancshares Inc & USA & 106 & 275 & 378 & 37,67 \\
\hline Northern Trust Corp & USA & 132 & 298 & 375 & 25,50 \\
\hline Ally Financial Inc & USA & 173 & 282 & 374 & 32,62 \\
\hline
\end{tabular}

Fonte: Sistema Economatica (2018)

Aliado aos lucros anuais, o banco Itaú Unibanco coleciona reconhecimentos em gestão de pessoas, como o indicado pelo site da GPTW (Great Place To Work) que é uma renomada autoridade global no mundo do trabalho no que tange o assunto. Em 2018 a instituição se posiciona em $13^{\circ}$ das 20 melhores empresas para se trabalhar na américa latina, tendo como amostra seus funcionários de agências bancárias.

Tendo em vista esses dados e o autor sendo um bancário, inspirouse o real objetivo deste estudo teórico-empírico, que é entender o quão eficiente o modelo de gestão de pessoas do Itaú Unibanco é para que possa ser atribuída destaque com autoridades globais e responder: $O$ modelo de gestão do Itaú Unibanco é percebido por seus colaboradores? Isso contribui para a motivação dos colaboradores que trabalham para esta empresa? 


\subsection{Objetivo Final}

O presente trabalho tem como objetivo realizar uma análise crítica do modelo de gestão bancária moderna, tendo como amostra funcionários do Itaú Unibanco, visando identificar pontos fortes, pontos fracos e possíveis oportunidades de melhoria desta empresa.

\subsection{Objetivos Intermediários}

Para chegar ao objetivo final desse estudo, teremos como objetivos intermediários:

- Descrever e comparar os principais modelos de gestão de pessoas;

- Realizar mapeamento das práticas de gestão do Itaú Unibanco que permitem definir um modelo próprio;

- Aferir a motivação dos colaboradores do Itaú Unibanco;

- Levantar percepções dos funcionários do Itaú Unibanco sobre o seu modelo de gestão;

- Estabelecer uma associação entre o modelo de gestão do Itaú Unibanco e a motivação de seus colaboradores.

\subsection{Delimitação do Estudo}

O estudo será delimitado a agências do Itaú Unibanco localizadas na região centro e zona sul do Rio de Janeiro, onde o autor trabalha atualmente, sendo utilizado como amostras do estudo bancários das agências dessas regiões.

\subsection{Relevância do Estudo}

Como dito no item 1.1., os bancos são a força motriz de qualquer economia, e, portanto, estão em constante adaptação ao mercado e sempre prevendo possíveis cenários onde possam ter oportunidades de melhoria e atuação. 
Tendo esse espírito empreendedor, o presente estudo poderá ser utilizado pelo próprio banco Itaú Unibanco como base para compreender, de forma acadêmica, os princípios e os efeitos de um modelo de gestão sobre os colaboradores de uma organização, assim como outros bancos interessados neste material para análise de sua gestão bancária e avaliar o quão adequados realmente estão para o cumprimento de seus objetivos e diretrizes. 


\section{Referencial Teórico}

\subsection{Gestão Bancária}

Segundo Maciel e Costa (2014), no sistema financeiro dissemina-se a ideia de banco virtual, disponibilizado para ser acessado por computadores, telefones, celulares, etc. Com isso, criam-se agências automatizadas, nas quais 0 atendimento se realiza sem a presença de clientes, permitindo que o mesmo consulte e movimente suas contas de suas residências, escritórios, de onde bem entender e necessitar. Tecnologias como os microchips inseridos nos cartões auxiliam na segurança do cliente, no armazenamento de informações e no uso do débito automático, dispensando 0 uso de cheques ou cédulas. Autoatendimento torna-se cada vez mais expressivo, assim como as centrais de atendimento telefônico oferecem a cada dia mais serviços. São mais de 38 mil postos eletrônicos contra cerca de 19 mil agências em todo os país.

Ainda conforme Maciel e Costa (2014) essas inovações trazem facilidades para os clientes, reduzindo a necessidade de sua presença física nas agências, mas reduzem o trabalho vivo. É interessante constatar que gradativamente o lucro dos bancos privados advém cada vez mais de receitas geradas a partir das transações via canais alternativos e que a cobrança das metas para aumentar a lucratividade do setor se faz mais presente no trabalho cotidiano dos bancários.

O processo de automação nos bancos trouxe mudanças significativas na forma como os bancários executam seu trabalho. Ele facilita e simplifica os procedimentos, trazendo flexibilidade e velocidade entre as operações, e transfere grande parte das atividades para as máquinas e para os clientes. A quantidade de informações na forma de papéis é bastante reduzida, mas ela se torna virtual e se avoluma por essa via. 
A gestão flexível exige produção enxuta, capaz de permitir agilidade, e um modelo de retribuição que deve considerar o desempenho dos indivíduos sob as premissas de flexibilidade e de adaptabilidade e buscam mobilizar conhecimentos, competências, habilidades, atitudes, significados e transformar-se em ações e, principalmente, em resultados para a empresa.

Somada a gestão, existem programas de qualidade que incorporam essa expectativa e o modelo de gestão por competência tem sido usado para aperfeiçoá-los de modo a promover a harmonização e comprometimento dos colaboradores com os objetivos da organização bancária.

\subsection{Gerenciamento Pelas Diretrizes}

O gerenciamento pelas diretrizes são atividades que tem prioridade de manter a empresa competitiva através do alcance de metas por todos os participantes da organização seja ele estratégico, tático ou operacional (Falconi, 2013). Também se traduz em uma forma de unificar a visão ou direcionar todos os esforços das diversas áreas da organização para o mesmo objetivo de buscar o atingimento da visão estratégica colocado pelo nível mais alto.

Ainda segundo Falconi (2013) o Plano Anual conta com metas anuais e seus respectivos planos de ação, constando em um orçamento efetivo para suportar financeiramente projetos prioritários e indispensáveis para atingir as metas.

Desta forma, a visão do planejamento estratégico se desmembra em objetivos estratégicos que é "quebrado" em pequenos pedaços, fáceis de serem compreendidos e executado independente da função do colaborador na organização. No Gerenciamento pelas Diretrizes a divulgação das orientações da alta administração é conduzida de forma metódica através do desdobramento das diretrizes. Desdobrar uma diretriz significa dividi-la em várias outras diretrizes sob a 
responsabilidade de outras pessoas, num relacionamento meio-fim, de forma a garantir o cumprimento da diretriz original.

Falcone (2013) ainda coloca que o processo de implantação do Gerenciamento pelas Diretrizes corresponde a um crescimento das pessoas decorrente do aprendizado, através do treinamento e prática. No processo de desmembramento de metas e objetivos estratégicos as próprias áreas desenvolverão a "consciência do problema" e o objetivo é exatamente fazer com que a visão inovadora se aflore para atingir as metas específicas.

Após esta identificação do problema as áreas acabam desenvolvendo o planejamento específico e acabam enxergando problemas de interfaces entre áreas e stakeholders, isto é desenvolvem o gerenciamento para alcançar as diretrizes vindas da necessidade da empresa.

O gerenciamento pelas diretrizes tem como vantagens:

Alinhamento: através do desmembramento de estratégias da direção, os setores e áreas da organização trabalham dentro da visão estratégica, somando forças no alcance de metas específicas para a principal.

> Resultados: como os objetivos e metas são bem especificados e definidos, a cobrança por resultados fica facilitada, mesmo de níveis hierárquicos iguais a cobrança pode existir, pois tudo está relacionado e assim se cria um ambiente competitivo internamento para alcançar resultados positivos de forma rápida e com eficiência.

- Estabilidade: quando todos os níveis da gestão buscam metas quantitativas e específicas para atender a visão estratégica, todos sabem o que devem fazer. Isto cria um ambiente mais estável, pois todos sabem o que a organização deseja alcançar e o seu grau de importância em sua participação no atingimento da visão. 
Objetividade e eficiência: como tudo está bem definido as operações diminuem o desperdício de tempo e retrabalhos nos processos e consequentemente a satisfação dos clientes melhora.

Em contrapartida as desvantagens são:

Pressão contínua: A maior desvantagem é em relação a pressão sofrida pelos colaboradores da organização, pois com os indicadores e metas expostos a pressão se torna parte da vida do colaborador, fazendo com que o Gerenciamento pelas Diretrizes tenha um efeito contrário, diminuindo a produtividade. Por isso o perfil das pessoas deve ser avaliado, para que não venham desestimular a capacidade criativa, já que estas ficam mais tempo olhando para os indicadores do que desenvolvendo suas funções, que agregam valor e naturalmente alcançando as metas propostas.

\subsection{Administração no Brasil}

Segundo Sobral e Peci (2012, p.16), a administração brasileira apresenta traços que the permitem distinguir-se de outras culturas nacionais que, por vezes, podem ser identificados como vantagens em relação as demais nações.

\subsubsection{Traços Culturais da Administração Brasileira}

Conforme Sobral e Peci (2012, p.16), um estudo sobre o estilo brasileiro de administrar foi realizado por Betânia Barros e Marco Aurélio Prates com 2500 administradores em 2012, em que estes pesquisadores desenvolveram um modelo de interpretação da cultura brasileira segundo quatro grandes subsistemas: o institucional, o pessoal, o dos líderes e o dos liderados.

Esses subsistemas se interceptam, dando então origem aos traços culturais da administração brasileira, que são: concentração de poder, personalismo, postura de espectador, aversão ao conflito, formalismo, lealdade às pessoas, paternalismo, flexibilidade e impunidade. 
A figura 2 define como esses subsistemas se entrelaçam.

Figure 2 - O estilo brasileiro de administrar segundo Barros e Prates

\section{O estilo brasileiro de administrar}

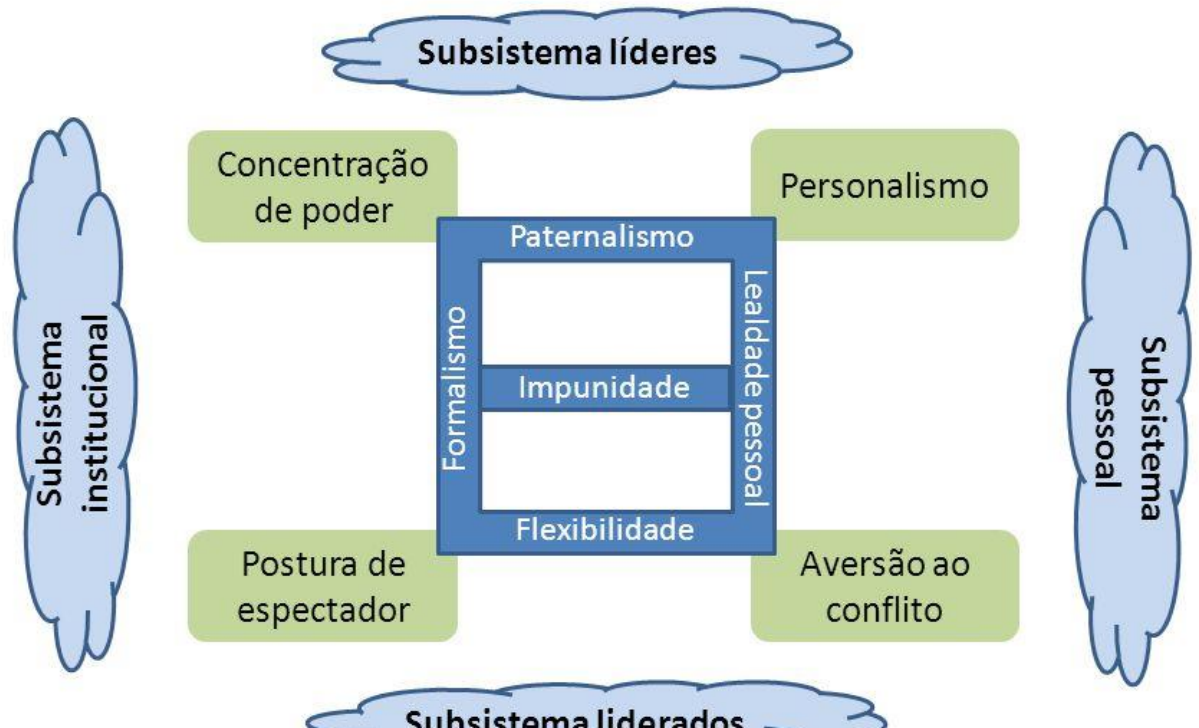

Fonte: Sobral e Peci (2012)

Dentre os traços identificados da pesquisa, três chamam a atenção para validação do estudo proposto neste documento, que são:

- Personalismo: Representa o lado pessoal da relação líderliderado e reflete a tendência para cultivar a proximidade e o afeto nas relações interpessoais. Pessoas são consideradas nos processos decisórios não sendo encaradas como ferramentas para atingimento de metas;

- Paternalismo: Quando a concentração de poder e o personalismo do líder perante os liderados manifesta-se em patriarcalismo, assumindo papel de pai e protetor, atendendo as necessidades de seu grupo, e em patrimonialismo, assumindo papel de líder supremo e absoluto, impondo sua vontade aos membros do grupo. 
- Flexibilidade: É o famoso "jeitinho brasileiro", que permite a articulação entre as regras inflexíveis e formais e um estilo de relacionamento caracterizado pela informalidade e amizade. Dos traços existentes, é o que pode trazer mais vantagens ao administrador brasileiro, uma vez que pode resultar em agilidade do processo decisório e soluções inovadoras que ultrapassam barreiras encontradas na gestão.

Esses três traços chamam atenção por estarem relacionados mais diretamente a relação líder-liderado e a forma de gerir no Brasil como um todo, e servirá como referência para comparação e análise do modelo de gestão do Itaú Unibanco.

\subsection{Cultura Organizacional}

A cultura organizacional conforme salientam Sobral e Peci (2012, p.73), é definida como um conjunto de significados, normas e valores compartilhados pelos membros de uma organização e serve como diferenciação de uma empresa para outra.

\subsection{Liderança}

Segundo Chiavenato (2012, p.117), liderança é necessária em todos os tipos de organização humana, seja nas empresas, seja em cada um de seus departamentos. O administrador precisa conhecer a natureza humana e saber conduzir pessoas, isto é, liderar. Pode ser visualizada por diversos ângulos: influência interpessoal, redução de incerteza de um grupo, relação funcional em líder e subordinados e processo em função do líder.

Existem ainda, teorias acerca deste tema, que identificam estilos de liderança conhecidos, conforme ilustra a figura abaixo: 
Figure 3 - Teorias sobre liderança segundo Chiavenato

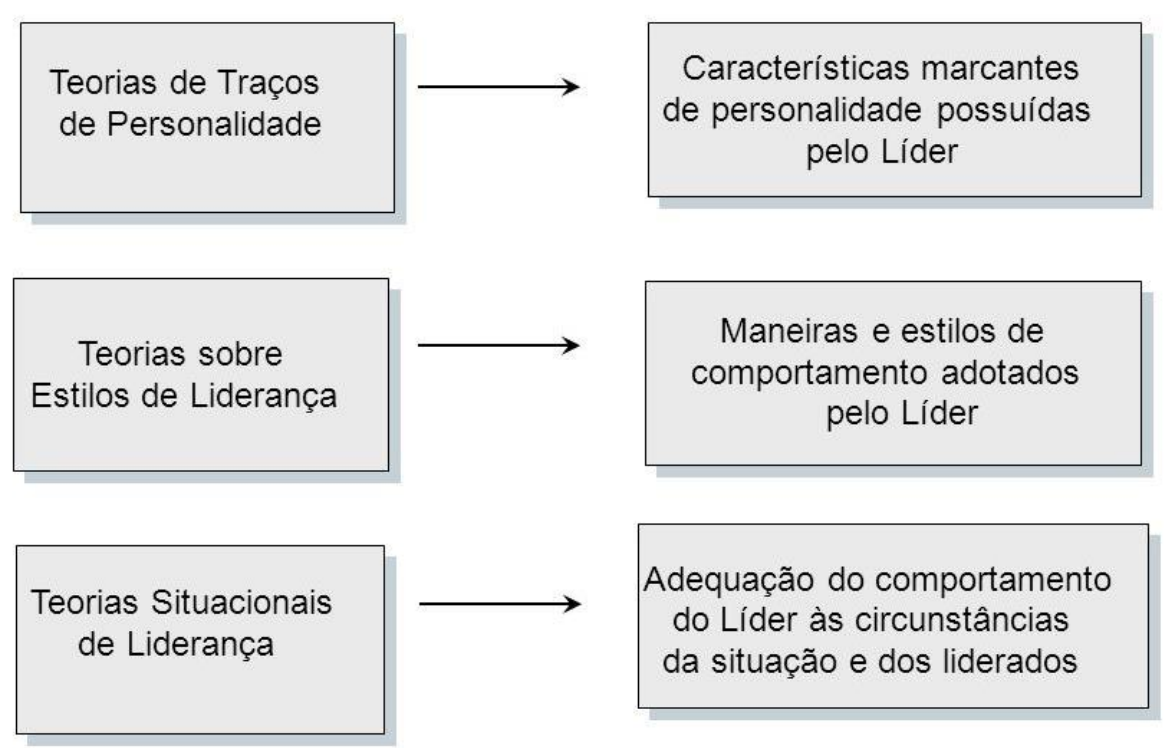

Fonte: Chiavenato, 2012

\subsection{Liderança Transacional e Transformacional}

Conforme Calaça e Vizeu (setembro de 2013), James MacGregor Burns (1978) foi o primeiro a chamar a atenção para o conceito de liderança transformacional. Ele afirmou que a liderança transacional e transformacional se baseavam em "relações" e "poder".

$\mathrm{Na}$ década de 80, então, Bernard Bass alargou o ponto de vista de Burns e desenvolveu estudos sobre liderança propondo a contextualização de dois novos estilos de liderança: transacional e transformacional. Segundo Bass, a liderança transacional incide no esclarecimento do papel e dos requisitos das tarefas dos liderados, bem como na atribuição de recompensas e de castigos pelo seu desempenho efetivo (Kinicki \& Kreitner, 2006).

Daí que este tipo de líder conduza e motive os seus liderados através do processo de troca, de transação (recompensa/desempenho). A liderança transformacional incorpora não só uma troca nos propósitos e recursos daqueles envolvidos na relação líder-seguidor, mas uma elevação de ambos - uma mudança para melhor. A liderança transformacional, torna-se, em última análise, moral pois eleva o nível de conduta humana e a aspiração moral do líder e do liderado, e assim tem 
um efeito de transformação em ambos Enquanto que Burns considera as práticas de liderança transformacional e transacional como extremos opostos de um continuum (essencialmente formas de liderança mais e menos eficazes), Bass oferece uma concepção bastante diferente, uma teoria de liderança de dois fatores; formas de liderança transacional e transformacional, no seu ponto de vista, constroem-se um no outro (Avolio e Bass, 1999).

Na última década, Bernard Bass e Bruce Avolio (2004), propuseram uma nova abordagem sobre a liderança sendo apresentada como uma teoria de maior alcance acerca do que se entende de liderança. Os autores dessa teoria, propuseram que o comportamento de liderança variava ao longo de um continuum da liderança laisser-faire (o fracasso geral em assumir responsabilidades para liderar) à liderança transacional e à liderança transformacional.

A liderança transacional e transformacional são, portanto, dois modelos que se complementam: "A liderança transformacional é construída em cima da liderança transacional - produz, nos liderados, níveis de esforço e de desempenho que vão além dos obtidos apenas na abordagem transacional" (Robbins, 2005, p. 319).

Bass admite, no entanto, que ambos os estilos podem ser eficazes em situações distintas: "O transformacional em períodos de fundação organizacional e de mudança, e o transacional em períodos de evolução lenta e ambientes relativamente estáveis" (Rego e Cunha, 2004, p. 235). A liderança transformacional transforma os liderados no sentido de estes passarem a perseguir os objetivos da organização deixando os seus próprios interesses para segundo plano.

\subsection{Motivação Humana}

Com base em estudos behavioristas, Chiavenato (2012, p.307) disserta que para entender como as pessoas se comportam, torna-se necessário o estudo da motivação humana. $O$ administrador precisa compreender as necessidades humanas para melhor entender 0 
comportamento humano e utilizar a motivação como poderoso meio para melhorar a qualidade de vida dentro das organizações. Chiavenato se apoia em duas teorias. São elas:

\subsubsection{Hierarquia das Necessidades de Maslow}

Segundo Chiavenato (2012, p. 307) Maslow apresenta uma teoria da motivação que baseia-se em organizar as necessidades humanas em níveis, de forma hierárquica de importância e influência, como se fosse uma pirâmide. A figura abaixo exemplifica essa pirâmide e os meios de satisfação que correspondem a cada nível:

Figure 4 - A hierarquia das necessidades humanas e os meios de satisfação

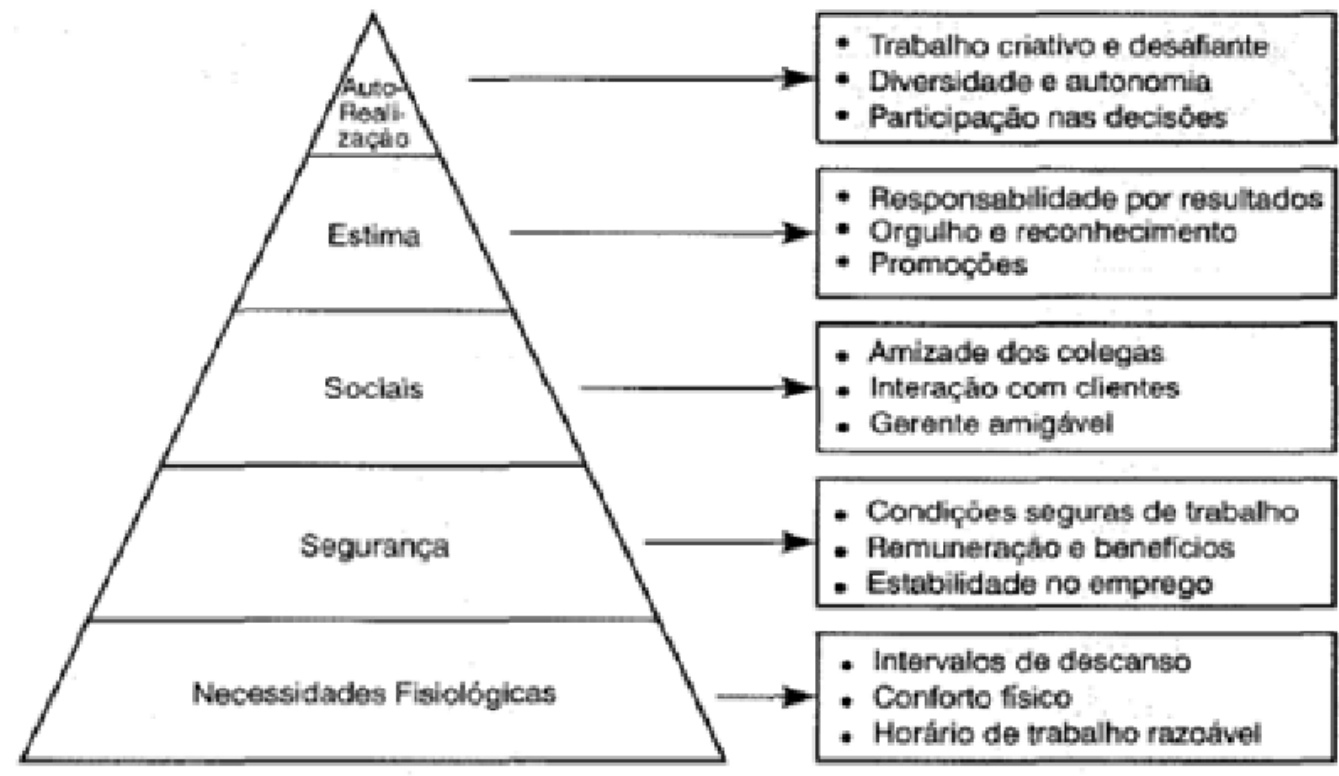

Fonte: Chiavenato, 2012, p.309

As necessidades humanas assumem formas e expressões que variam conforme o indivíduo. Entender essas nuâncias permite analisar de forma clara se os colaboradores estão ou não motivados.

\subsubsection{Teoria dos Dois Fatores de Herzberg}

Outra teoria citado por Chiavenato (2012, p.309) para explicar o comportamento das pessoas no ambiente organizacional e para ela, existem dois fatores: 
a) Fatores higiênicos (ou fatores extrínsecos): São fatores externos as pessoas e abrangem apenas as condições dentro das quais elas desempenham seu trabalho. Essas condições são administradas e decididas pelas empresas. As principais são: salário, benefícios sociais, tipo de chefia ou supervisão que as pessoas recebem de seus superiores, condições físicas e ambientais de trabalho, entre outros.

b) Fatores motivacionais (ou intrínsecos): Estão relacionados com o conteúdo do cargo e com a natureza das tarefas que a pessoa executa. Esses fatores estão sob o controle do indivíduo, e envolvem sentimentos de crescimento individual, reconhecimento e autorrealização, e depende das tarefas que o indivíduo realiza no seu trabalho. Geralmente eles são atrelados a um significado psicológico ao indivíduo quando as tarefas ou cargos não são arranjadas somente para atender eficiência e economia, mas sim, desafios e conquistas, tornando o efeito de motivação sobre o indivíduo profundo e estável, gerando satisfação.

Teorias como essas ajudam o administrador a identificar se sua equipe está alinhando sua motivação com o resultado da organização.

\subsection{Gestão de Conhecimento}

Segundo Chiavenato (2012, p.562), na era atual, onde cada vez mais a informação é valiosa para gestão dos negócios, o capital intelectual de uma empresa é trabalhada com esmero e os indivíduos cada vez menos são encarados como simples ferramentas para alcance das metas organizacionais. Conhecimento é a informação estruturada que tem valor para a organização, e pode conduzir a novas formas inovadoras de executar as tarefas da organização, formas mais concisas e práticas de gerar decisões importantes, entre outras coisas.

Sendo assim, as organizações bem-sucedidas são aquelas que sabem conquistar e motivar as pessoas para que as mesmas aprendam e 
apliquem seus conhecimentos na solução dos problemas e na busca da inovação rumo à excelência.

Portanto, a gestão do conhecimento não só é necessária, como é uma fator de vantagem competitiva, pois é um processo integrado destinado a criar, organizar, disseminar e intensificar o conhecimento com o objetivo de melhorar o desempenho global de uma organização.

Entender como o Itaú Unibanco gere seu capital intelectual e o conhecimento de sua organização pode ser um indicador importante para validação deste estudo.

\subsection{Meritocracia}

Conforme o site Sobre Administração (Março, 2011), Meritocracia (do latim mereo, merecer, obter) significa premiar os funcionários pelo seu desempenho e resultados alcançados, levando-os aos postos mais elevados na hierarquia através de seus próprios méritos.

A meritocracia é muito utilizada em empresas que possuem um alto nível de competitividade no mercado, que precisam reter seus melhores talentos antes que eles se mudem para a concorrência. É através dela que os gestores mostram que estão acompanhando de perto 0 desenvolvimento destes profissionais. É assim, também, que os funcionários se sentem observados e avaliados da melhor forma, sem temer o famoso "Ql" (quem indicou), comum nas organizações desde que o mundo é mundo.

Porém, como em todo assunto relevante para a Administração, a Meritocracia provoca algumas discussões sobre a forma como os funcionários se relacionam no ambiente de trabalho, seu comprometimento e dedicação com as tarefas. E também a percepção que seus gestores tem sobre estas questões.

A Psicóloga educacional e empresarial, Silvia Osso, questiona esta situação em seu blog e dá um exemplo de uma situação em que a Meritocracia gera algumas discussões importantes no meio empresarial, confira: 
"Veja o caso de um gestor que tem dois colaboradores do mesmo nível, que ganham o mesmo salário e têm o mesmo plano de benefícios. Um é pontual, cumpre prazos, é confiável e seu trabalho é de qualidade; o outro, nem tanto. Quem está sendo recompensado? Naturalmente, o segundo. Matematicamente, o segundo ganha mais porque faz menos. E como fica a motivação do primeiro? Se isso acontece em sua empresa, cuidado! É uma das melhores receitas para reter os segundos e perder os primeiros..."

Neste caso apresentado, é muito fácil medir a diferença de desempenho entre os trabalhadores, por causa das mesmas condições de trabalho e remuneração, mas nem sempre é assim. Por isso, é importante que o gestor que decida por implementar a Meritocracia em sua empresa fique de olhos abertos com relação ao comportamento de seus funcionários, seus hábitos de trabalho e as relações com os demais colegas. Uma boa observação destes fatores pode facilitar a implantação de possíveis modificações no processo de análise de desempenho na empresa.

É sabido que a Meritocracia gera diversos problemas para a empresa, no que diz respeito à insatisfação de alguns funcionários, mas é preciso lembrar que ter um sistema de avaliação de desempenho baseado realmente no desempenho do funcionário é muito melhor do que o velho sistema de indicação e coleguismo. Por isso, os colaboradores precisam também apoiar a empresa nesta avaliação e focar mais no trabalho do que em questões afins. Assim, os melhores talentos sempre se sobressairão, chamando a atenção dos gestores para si.

\subsection{Modelo Atual de Empresa de Sucesso}

Segundo a revista pequenas empresas e grandes negócios (Abril, 2016), gestão de qualidade e capacidade de inovar foram os principais quesitos avaliados para escolher os vencedores da premiação nacional do MPE Brasil 2015 - Prêmio de Competitividade para Micro e Pequenas Empresas. 
Para Jairo Martins da Silva, superintendente geral da FNQ, a gestão é a saída para a crise. "Não tenho dúvida de que a saída para o nosso país é gestão. Acho que diante da crise o grande rearranjo econômico será por meio do empreendedorismo. $E$ as empresas estão conscientes e querem começar certo", diz Silva. "Essas empresas são exemplo de que com vontade e determinação é possível ter sucesso mesmo em cenários voláteis."

Durante o evento de premiação, o empresário Jorge Gerdau Johannpeter, presidente do conselho superior do MBC, falou aos empreendedores sobre o papel do empresariado na sociedade. "Os negócios são as pessoas. Em uma época de crise, os verdadeiros vencedores são os que conseguirem passar pela dificuldade junto com a equipe", afirma.

Com isso, é ressaltado que o pavimento de toda empresa de sucesso são as pessoas que constituem a organização. $O$ empreendedorismo atual é baseado principalmente na gestão adequada de seu capital humano, muitas vezes mais até que o financeiro. 


\section{Métodos e Procedimentos de Coleta e de Análise de Dados do Estudo}

\subsection{Etapas de Coleta de Dados}

Este estudo tem como objetivo validar a eficiência do modelo de gestão utilizado no Itaú Unibanco, de modo a justificar sua qualificação como uma das melhores empresas para se trabalhar, e também checar se seus colaboradores e gestores percebem essa qualificação.

Para tal, foi necessário abordar duas frentes: os gestores e os demais colaboradores.

Os gestores corresponderam a primeira etapa da coleta de dados, onde realizou-se uma pesquisa exploratória com 10 gestores de diferentes agências do varejo. Nesta pesquisa, foram formuladas 10 perguntas acerca do que estes gestores entendem sobre o papel do gestor e da liderança, como eles identificam as necessidades e motivações de sua equipe e quais seus desafios como gestores.

A partir desta pesquisa, as informações coletadas foram usadas não só para a validação deste estudo, identificando o modelo de gestão praticado nas agências, mas como também para a formulação da segunda etapa, que seria os formulários direcionados aos demais colaboradores.

Com base no que os gestores responderam, foram criados formulários com 17 perguntas, em forma de pesquisa quantitativa que busca mensurar a percepção e a valorização dos colaboradores acerca de seus gestores e ainda, como isso afeta a motivação dos mesmos.

A justificativa para utilização destes métodos foi de cruzar a percepção de líderes e liderados e validar o modelo de gestão do banco Itaú Unibanco como eficiente e justificar sua posição como uma das melhores empresas para se trabalhar. 


\subsection{Fontes de Informação Selecionadas Para Coleta de Dados}

Como fontes de informação para coleta de dados, foram utilizados neste estudo artigos sobre modelos de gestão, artigos sobre ambiente bancário, pesquisas em sites e órgãos envolvidos em avaliação de empresas, o próprio site do Itaú Unibanco, teorias sobre motivação, liderança e gestão de pessoas e de conhecimento de livros utilizados durante o currículo acadêmico.

Já para realização das pesquisas, a amostra utilizada foi gestores e colaboradores da rede de agências do banco Itaú Unibanco, visto que o autor também trabalha no banco e tem fácil acesso a estes.

\subsection{Procedimentos e Instrumentos de Coleta de Dados Utilizados no Estudo}

A primeira etapa da coleta de dados foi realizada entre os dias $24 \mathrm{e}$ 27 de setembro de 2018, nas respectivas agências de cada um dos entrevistados. Para o momento das entrevistas, foi utilizado um formulários de perguntas abertas aos entrevistados, de forma a captar a opinião dos mesmos acerca dos temas tratados neste estudo para validálo. Foram gravados aúdios com as respostas dos entrevistados para documentar e analisar detalhadamente as informações obtidas.

$\mathrm{Na}$ segunda etapa o método utilizado foi menos pessoal, através de um formulário com perguntas de múltipla escolha que foi enviado aos entrevistados via redes sociais (Whats App, Messenger), e o tratamento das respostas foi feito via aplicativo da Google (Google Docs).

\subsection{Formas de Tratamento e Análise do Dados Coletados para o Estudo}

A primeira etapa, que consistia na entrevista com gestores, foi de caráter exploratório e serviu não só para validar o problema sugerido por este estudo como para elaboração da segunda etapa, que constitui no formulário encaminhado aos demais colaboradores.

Já na segunda etapa, com as informações obtidas com os gestores, foi possível elaborar de forma mais contundente perguntas objetivas 
sobre como os colaboradores percebem seus gestores e liderança, assim como suas motivações.

Com isso, foi possível levantar hipóteses e conclusões que validam o estudo, considerando o referencial teórico utilizado.

\subsection{Limitações do Estudo}

Esse estudo possui limitações principalmente quando considerado sua coleta de dados, pois para executá-lo, foi utilizado uma amostra que é a mais próxima do autor, que também trabalha na empresa em análise. $A$ amostra é basicamente gestores e colaboradores que pertencem a mesma região do autor, sendo assim, pertencendo a mesma gestão direta.

Portanto, a conclusão deste estudo não deve ser generalizada, visto a natureza do tema, a metodologia utilizada e a amostra. Porém seu resultado tem o intuito de inspirar futuros estudos da própria empresa para validar cada vez mais seu modelo de gestão e identificar boas práticas e possíveis melhorias, melhorando cada vez mais sua posição no mercado. 


\section{Apresentação e Análise dos Resultados}

\subsection{A Empresa}

Segundo o site do próprio Itaú Unibanco, ele é o maior banco privado do Brasil - e uma das maiores empresas do mundo, segundo ranking da Forbes, levando em conta atributos como negócios gerados, ativos e valor de mercado que om 91 anos de história e tradição, hoje conta com mais de 90 mil colaboradores, quase 60 milhões de clientes, mais de 95 mil acionistas, cerca de 5 mil agências no Brasil e também no exterior, já atuando em 21 países atualmente.

As agências bancárias, que são o principal serviço da empresa, contam com a área operacional, que é a que atua com numerário, funcionamento das agências físicas e a segurança das mesmas e área comercial, que atua mais diretamente com prospecção de negócios, captura de novos clientes e relacionamento.

A área operacional da agência é gerida pelo Gerente Operacional, que comanda diretamente o supervisor operacional e os caixas.

A área comercial por sua vez é gerida pelo Gerente Geral Comercial, que é responsável pelos atendentes e gerentes de relacionamento.

Ambas áreas tem metas distintas mas que se complementam, e atuam de forma independente, se auxiliando, para conseguirem atingir seus objetivos de curto e médio prazo.

Com lucros bilionários anualmente, o banco conta com mais de 90 anos de atuação como uma empresa de sucesso e de reconhecimento nacional.

\subsection{Modelo de Gestão de Pessoas Itaú Unibanco}

O modelo de gestão do Itaú Unibanco se diferencia pelos valores pregados pela empresa, que norteiam sua cultura organizacional, que 
mesma batiza de "Nosso Jeito de Fazer", conforme mostra a figura abaixo.

Figure 5 - Diretrizes do Nosso Jeito de Fazer do Itaú Unibanco

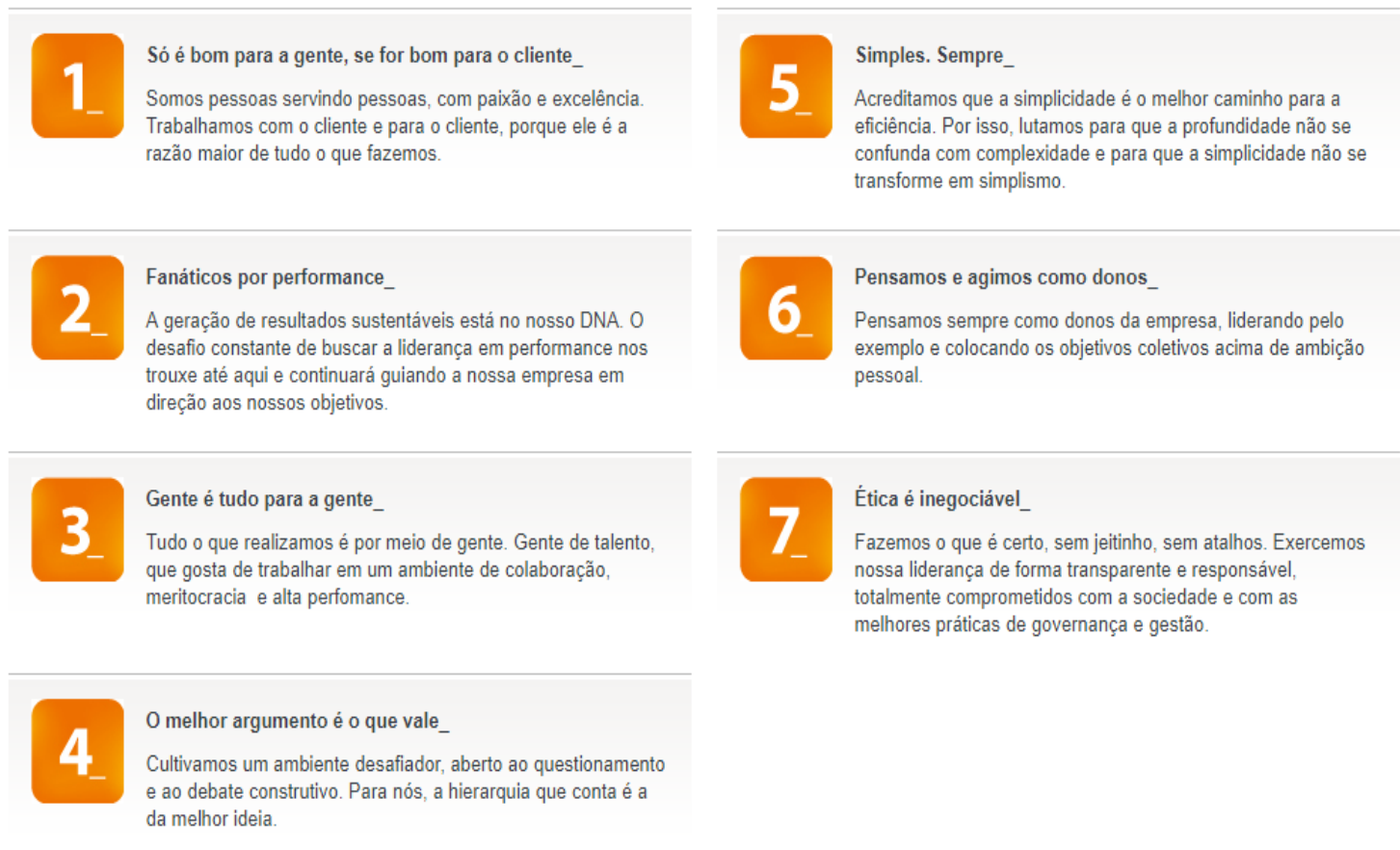

Fonte: Site do Itaú Unibanco

\subsection{Perfil dos Entrevistados}

Como já evidenciado no tópico 3.1 deste estudo, foram selecionados diferentes tipos de entrevistados para cada etapa da pesquisa.

$\mathrm{Na}$ primeira etapa foram escolhidos 10 gestores de diferentes agências da mesma região onde $\mathrm{o}$ autor atualmente trabalha. Foram escolhidos tanto gestores da área operacional como da área comercial das agências, sem qualquer restrição entre tempo de casa, sexo, idade ou experiência profissional.

$\mathrm{Na}$ segunda etapa foram escolhidos 24 colaboradores, de diversos cargos das áreas operacional e comercial, também sem restrição por tempo de casa, sexo, idade ou experiência profissional. 
Visto que o objetivo é analisar o modelo de gestão do Itaú Unibanco, a amostra foi verificada como suficiente para atender o propósito do estudo.

\subsection{Resultado das Entrevistas com Gestores}

Com o objetivo de preservar a confidencialidade quanto a identidade dos respondentes, serão utilizados números de 1 a 10 para se referir aos entrevistados e expor falas específicas de cada, quando necessário.

Para a primeira e segunda perguntas, em que se buscava verificar o papel do líder na empresa e como se avaliam nessa posição, foi bastante pontuada a função de capacitar e transformar pessoas, e os entrevistados assumem em suas falas que é uma tarefa inerente do cargo, pois visa o resultado em conjunto e facilitar a carreira de seus subordinados.

O entrevistado 1 diz que "a principal tarefa de um gestor é agregar valores, despertar perfis, capacitar pessoas, montar estratégias junto a equipe buscando sempre o resultado positivo."

Ainda nas perguntas 1 e 2, o entrevistado 7 ressalta: "Minha principal tarefa como gestor e como figura de liderança dentro da minha instituição é simplesmente fazer uma metanóia, que é uma mudança de mente na pessoa, tentar recuperar e inspirar pessoas para que elas consigam ver em mim um modelo a ser seguido, assim buscar liderar pela meritocracia(...)Com isso, me avalio como um gestor que preza pela liderança pelo exemplo, que reconhece o erro como aprendizagem e me qualifico como um líder que tira o melhor de cada um baseado na personalidade de cada um".

A partir destas falas, já vemos indícios no Itaú Unibanco do conceito de Liderança Transformacional, conforme definido por Bass (1981) e Robbins (2002), principalmente quando vemos em seu modelo de gestão institucional que "gente é tudo para a gente". Sendo assim, já é inato aos gestores do banco uma cultura organizacional em que os líderes promovem o incentivo ao desenvolvimento dos colaboradores, elevando 0 nível de relacionamento de trabalho a algo mais intrínseco, buscando a motivação interior e não só a recompensa pelo desempenho apenas. 
Também foi ressaltado pela maioria dos entrevistados que a proximidade e os feedbacks de "mão dupla" com a equipe facilitam a gestão, o entrosamento, o engajamento e o encarreiramento da equipe, mostrando que o estilo de liderança preza pelo personalismo, em que há certa proximidade entre líder e liderado. Não houve diferenças significantes de diálogo nessas questões.

A terceira, quarta e quinta perguntas visam buscar a percepção dos gestores sobre sua equipe: o que os colaboradores pensam $e$ reconhecem acerca de seus líderes, como estes últimos conseguem identificar isso e quão importante é o papel da liderança.

Os entrevistados reforçaram que a delegação de tarefas é muito importante para o desenvolvimento das pessoas, pois evita deixa-las na zona de conforto e garante a participação ativa na gestão. Isso mostra que a gestão por competência se faz presente no Itaú Unibanco, visto que as lacunas de conhecimento sobre a prática dos afazeres da agência são preenchidos pela delegação de tarefas aos colaboradores, que se motivam por conhecer cada vez mais a realidade bancária e sua habilidade como profissional da área.

Para identificar a motivação de cada um dos colaboradores, os gestores buscam em suas gestões sempre procurar o que incentiva seus subordinados com as práticas citadas no parágrafo anterior, e buscam extrair o melhor de cada de acordo com suas competências latentes e seus limites, gerando resultados sustentáveis.

Ainda foi citado que desafios são essenciais para despertar a iniciativa dos colaboradores, pois trás um incentivo interior de conquista aos funcionários, mostrando indícios da teoria do dois fatores de Herzsberg, em que a motivação é extraída com fatores que são internos ao indivíduo, como delegação de tarefas novas e de maior responsabilidade.

Para a sexta pergunta, que buscava entender qual tipo de gestão era a mais percebida dentro do banco e qual os entrevistados mais se identificavam, alguns citaram aspectos como personalidade, ressaltando que a comunicação com as pessoas, a coragem e iniciativa são essenciais. 
O destaque foi para o entrevistado 7: "Existem alguns traços dentro do banco né?! A gente tem dois modelos, que são o de Liderança Diretiva e o de Liderança Participativa (...)sendo a primeira aquela que você dá um 'norte' para o colaborador e já ensina ele o 'caminho das pedras', que é mais indicado para pessoas de baixa energia (...) e a segunda, que é um tipo de liderança mais indicado para quem tem mais iniciativa, pessoas mais 'aceleradas', para que você estimule essa pessoa a desenvolver competências de gestão, de liderança, pois caso seja diretivo com essas pessoas, corre-se o risco de retrair o potencial desse colaborador."

Essa visão casa bastante com a teoria de a teoria de Liderança de Bass e Robbins, mais pelo fato do gestor ter identificado que a liderança deve adequar sua gestão de acordo com a iniciativa mostrada por seus colaboradores, sendo assim mais assertivo.

Para a sétima pergunta, que visava captar a percepção dos gestores acerca da presença de meritocracia ou paternalismo no banco, praticamente todos reforçam que a empresa preza totalmente pela meritocracia, e que o paternalismo é confundido com capacidade de fazer "network". Conforme fala do entrevistado 7, "o reconhecimento do Itaú Unibanco é totalmente meritocrático e eu vejo que tem pessoas que tem bom relacionamento com pares e gestores, que facilita sua ascensão."

A entrevistada 4 foi a única que respondeu com mais ressalva: "Percebe-se uma evolução contínua no reconhecimento meritocrático. Contudo, vemos em alguns casos avaliações de gestores que o paternalismo prevalece."

Essas declarações mostram que o banco Itaú Unibanco tem em seu modelo traços culturais de liderança personalista, que é bem comum nas empresas brasileiras, onde o relacionamento é facilitador de negócios.

Apesar de as vezes ser confundido com paternalismo, a maior parte dos gestores que o que há de fato é "network", que por sua vez gera aproximação e visibilidade aos que querem se encarreirar.

As perguntas 8 e 9 tratam da gestão das necessidades de cada colaborador e seus conflitos de interesse. No geral, todos prezam pela adequação da equipe com os resultados que tangem o banco, e que esta 
adequação varia de gestor para gestor. Então em base, o ideal é sempre criar um cenário em que todos ganhem sem gerar perdas, e caso haja conflitos, a prática imediata é atuar individualmente na raiz do problema, de modo a recuperar o colaborador e adequá-lo ao grupo.

"Já tive muitos funcionários individualistas, portanto, eu busco com números, com base, mostrar a este colaborador que em grupo, todos ganham. Sozinho, nem ele e nem a gente vai a lugar algum. Então se todos remarem em direção ao objetivo, a gente consegue chegar num resultado em comum,(...) porque o 'eu' não ganha jogo jogo sozinho(...)a empresa a qual a gente trabalha não é um esporte individual".

Fala do entrevistado 7

A última pergunta é uma das mais importantes, que busca identificar o que os gestores acreditam que seja o maior desafio deles. Segue algumas respostas:

"O maior desafio de um gestor é gerir conflitos enquanto gera resultado. Conseguir liderar de modo a contagiar a todos e conscientizálos de trabalharem sempre em equipe para todos se beneficiarem é uma das coisas mais gratificantes de se alcançar enquanto líder, principalmente em um ambiente desafiador que é o banco."

Fala do entrevistado 3

"O maior desafio de um gestor é conhecer cada um de sua equipe, $\mathrm{e}$ com isso transformar o time numa grande máquina de gerar resultados, com cada um exercendo a melhor função cabível a suas qualidades."

Fala do entrevistado 8

"Olha o maior desafio de um gestor na minha opinião, é conseguir entregar resultados expressivos, com foco na performance, é cuidar de pessoas, para que estas se desenvolvam e queiram novos desafios e por fim, deixar um legado, que é fundamental. É saber que você passou em uma agência e desenvolveu tudo e todos da melhor maneira possível e que mesma na sua ausência, todas as funções continuarão sendo exercidas com disciplina e competência."

Fala do entrevistado 7

Com isso, pode ser levantada a hipótese de que os gestores do Itaú Unibanco prezam pelas pessoas em sua gestão, que é exatamente o que 
está levando as empresas atuais ao sucesso, conforme mostram institutos que avaliam a área de administração. Possivelmente é o que levará a justificar a posição do banco na pesquisa do órgão GPTW (Great Place To Work).

\subsection{Resultado do Questionário com Demais Colaboradores}

Após entrevista realizada com os gestores, a segunda etapa da pesquisa foi formulada com base nos principais temas abordados nas respostas destes líderes do Itaú Unibanco. Um total de 24 colaboradores do banco participou dessa etapa, respondendo sobre afirmações que servem para confirmar a percepção de seus gestores acerca do modelo de gestão presente em seu ambiente profissional.

Quatro temas foram recorrentes, que são: Liderança, Motivação, Espírito de equipe e Meritocracia. Segue abaixo o que os colaboradores responderam acerca destes temas.

\subsubsection{Liderança}

Para este tema, foram feitas as seguintes afirmações:

1. Na sua agência, seu gestor lidera pelo o exemplo.

2. Seu líder apresenta excelência no alcance dos resultados e na execução dos processos.

3. Seu gestor preza pelo encarreiramento das pessoas.

4. Mesmo em condições adversas, seu gestor busca liderar de forma clara e calma, nunca deixando de ser objetivo.

5. Na sua agência seu gestor sempre preza pelo desenvolvimento de talentos e na recuperação e resgates de pessoas com baixo rendimento.

6. Em sua agência seu gestor busca mostrar os erros como forma de aprendizado.

O gráfico abaixo demonstra quantitativamente as respostas obtidas acerca destas afirmações enumeradas acima. 
Table 1 - Afirmações acerca de Liderança

\begin{tabular}{|c|c|c|c|c|c|c|c|}
\hline \multicolumn{8}{|c|}{20} \\
\hline \multirow[b]{3}{*}{$\begin{array}{l}\text { Concordo } \\
\text { Totalmente }\end{array}$} & 18 & & & & & & \\
\hline & 16 & & & & & & \\
\hline & 14 & & & & & & \\
\hline \multirow{3}{*}{$\begin{array}{l}\text { Concordo } \\
\text { Parcialmente } \\
\text { Discordo } \\
\text { Parcialmente }\end{array}$} & 12 & & & & & & \\
\hline & 10 & & & & & & \\
\hline & 8 & & & & & & \\
\hline \multirow{4}{*}{$\begin{array}{l}\text { Discordo } \\
\text { Totalmente }\end{array}$} & 6 & & & & 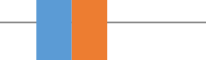 & & \\
\hline & 4 & & & & & & \\
\hline & 2 & & & & & & \\
\hline & 0 & Afirmação 1 & Afirmação 2 & Afirmação 3 & Afirmação 4 & Afirmação 5 & Afirmação 6 \\
\hline \multicolumn{2}{|c|}{ Concordo Totalmente } & 17 & 16 & 15 & 17 & 18 & 18 \\
\hline \multicolumn{2}{|c|}{ Concordo Parcialmente } & 6 & 6 & 9 & 7 & 6 & 6 \\
\hline \multicolumn{2}{|c|}{ Discordo Parcialmente } & 1 & 2 & 0 & 0 & 0 & 0 \\
\hline \multicolumn{2}{|c|}{ Discordo Totalmente } & 0 & 0 & 0 & 0 & 0 & 0 \\
\hline
\end{tabular}

Fonte: Autor

Vemos então que na grande maioria das perguntas, os colaboradores concordam totalmente com a percepção que seus gestores tem acerca de Liderança, representando em média $70 \%$ dos respondentes considerando todas as afirmações, com $28 \%$ em média concordando parcialmente e menos de $8 \%$ discordando parcialmente. Vale ressaltar que a quantidade de respondentes para cada nível de concordância teve poucas alterações para cada pergunta, mostrando uniformidade quanto a percepção dos colaboradores acerca do tema, com destaque as afirmações 5 e 6, que tratam especificamente da liderança desenvolvendo pessoas e utilizando os erros como aprendizado, onde tiveram mais respondentes concordando totalmente conforme mostra o gráfico acima.

\subsubsection{Motivação}

Para avaliar a percepção sobre a motivação, as seguintes afirmações foram avaliadas: 
1. Sua gestão no banco se preocupa com a sua motivação pessoal.

2. Você sempre se sente confortável para dialogar com seu gestor.

3. Na equipe há espaço para suas necessidades alinharem-se com o resultado da agência.

Seguem respostas no gráfico abaixo.

Table 2 - Afirmações acerca da Motivação

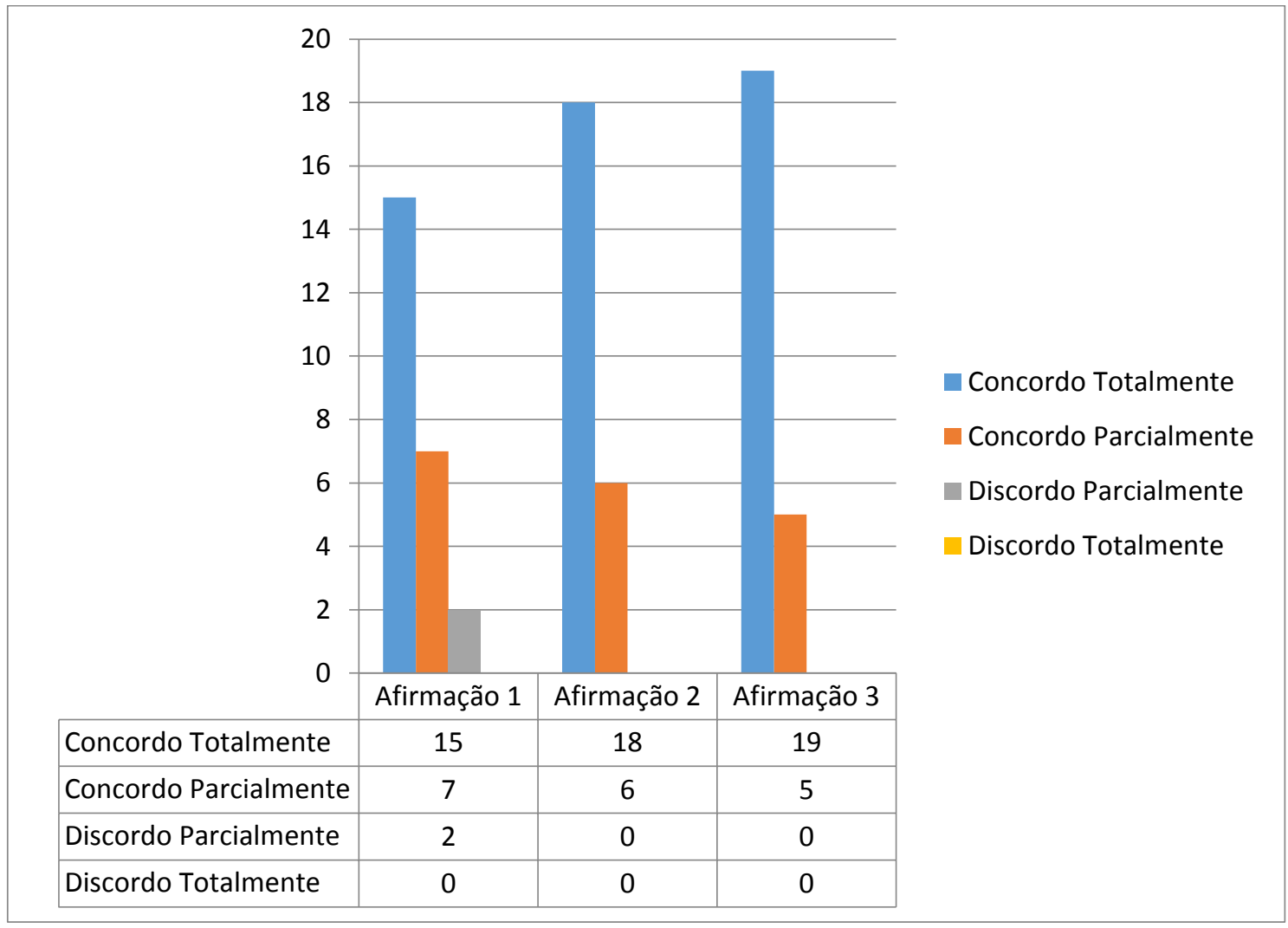

Fonte: Autor

E mais uma vez se repete a confirmação da visão dos líderes, com a maioria concordando totalmente com as percepções levantadas pelos seus gestores, em torno de $72 \%$ dos respondentes em média, $24 \%$ em média concordando parcialmente e bem poucos discordando, com uma média de $2 \%$ considerando todas as afirmações e ainda assim parcialmente. Houve uma leve oscilação da quantidade de resposta concordando totalmente em comparação ao tema anterior, mas ainda assim a visão dos gestores acerca da motivação está em maioria sendo percebida positivamente pelos seus colaboradores. 


\subsubsection{Espírito de equipe}

Para validar este tema, foram usadas as seguintes afirmativas:

1. Meu gestor incentiva o diálogo entre a equipe não importa o clima da agência.

2. Você se sente à vontade para participar das decisões da equipe e do gestor.

3. Seu gestor sabe identificar sempre quando dessintonia na equipe.

4. O gestor de sua equipe sabe gerir conflitos e atender a todos democraticamente.

Segue abaixo o gráfico com as respostas obtidas.

Table 3 - Afirmações acerca do Espírito em equipe

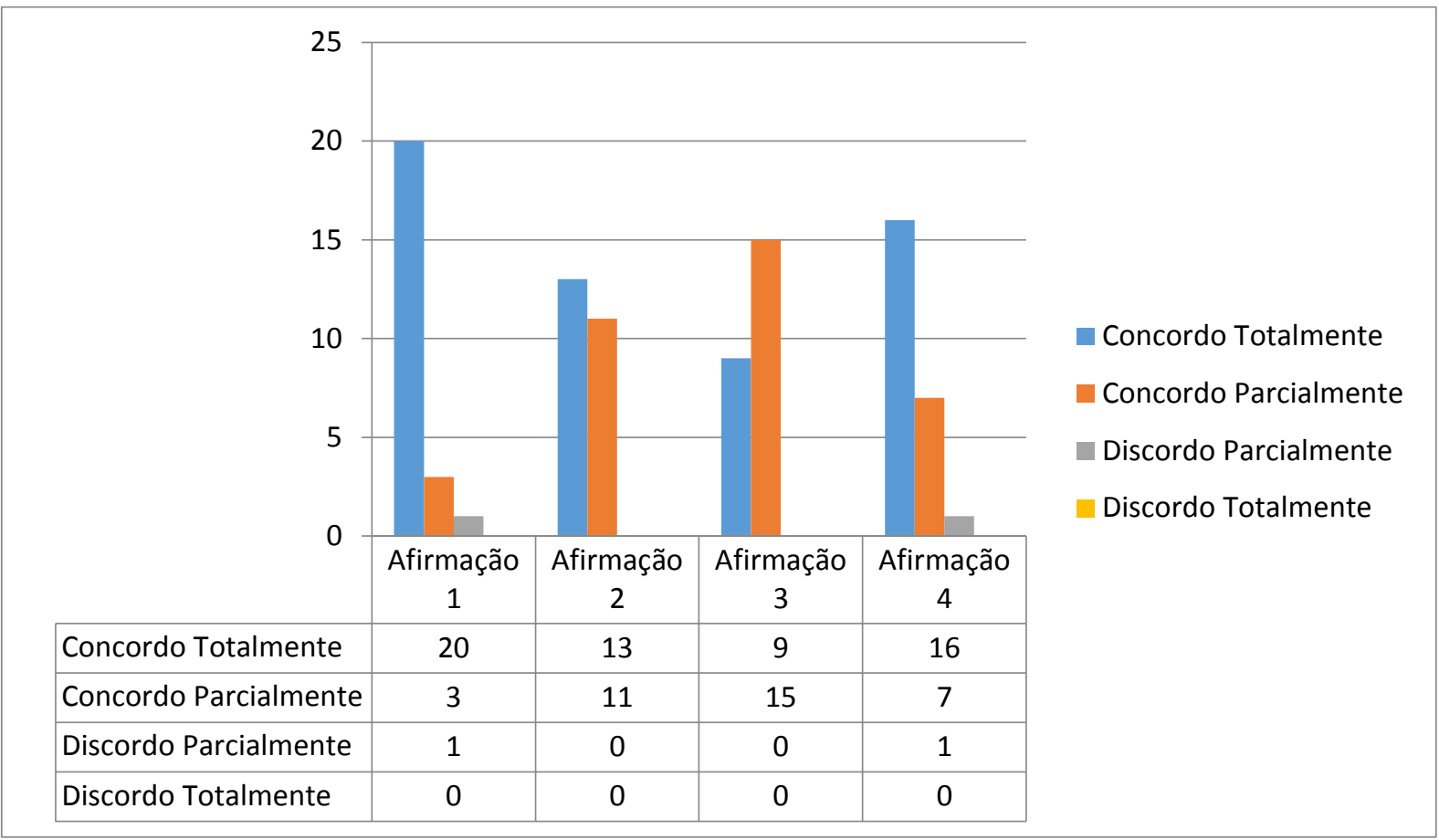

Fonte: Autor

O espírito de equipe já apresenta uma menor parcela em relação aos temas anteriores concordando totalmente com as afirmações, o que é bem visível considerando a variação apurada da primeira afirmação em relação as demais neste tema. Apesar disso, ainda temos concordando totalmente em média $61 \%$ dos respondentes. Concordando parcialmente temos em média $38 \%$ dos respondentes, com $2 \%$ apenas discordando parcialmente em média.

O resultado apurado ainda é positivo, porém começa a ser observada uma pequena perda de força em relação ao que gestores 
levantaram sobre Espírito de Equipe e o que seus colaboradores percebem disso em suas gestões.

\subsubsection{Meritocracia}

No tema de Meritocracia, os colaboradores opinaram sobre as seguintes afirmativas:

1. Você acredita que todos são reconhecidos pelo seu empenho.

2. $\mathrm{Na}$ sua equipe seu gestor reconhece talentos e incentiva a excelência.

3. Paternalismo é algo que não acontece em nenhum momento no banco.

4. Você sente que o banco, através de seu gestor, permite o encarreiramento e reconhecimento de seus funcionários de forma meritocrática sempre.

O gráfico com as respostas segue abaixo.

Table 4 - Afirmações acerca da Meritocracia

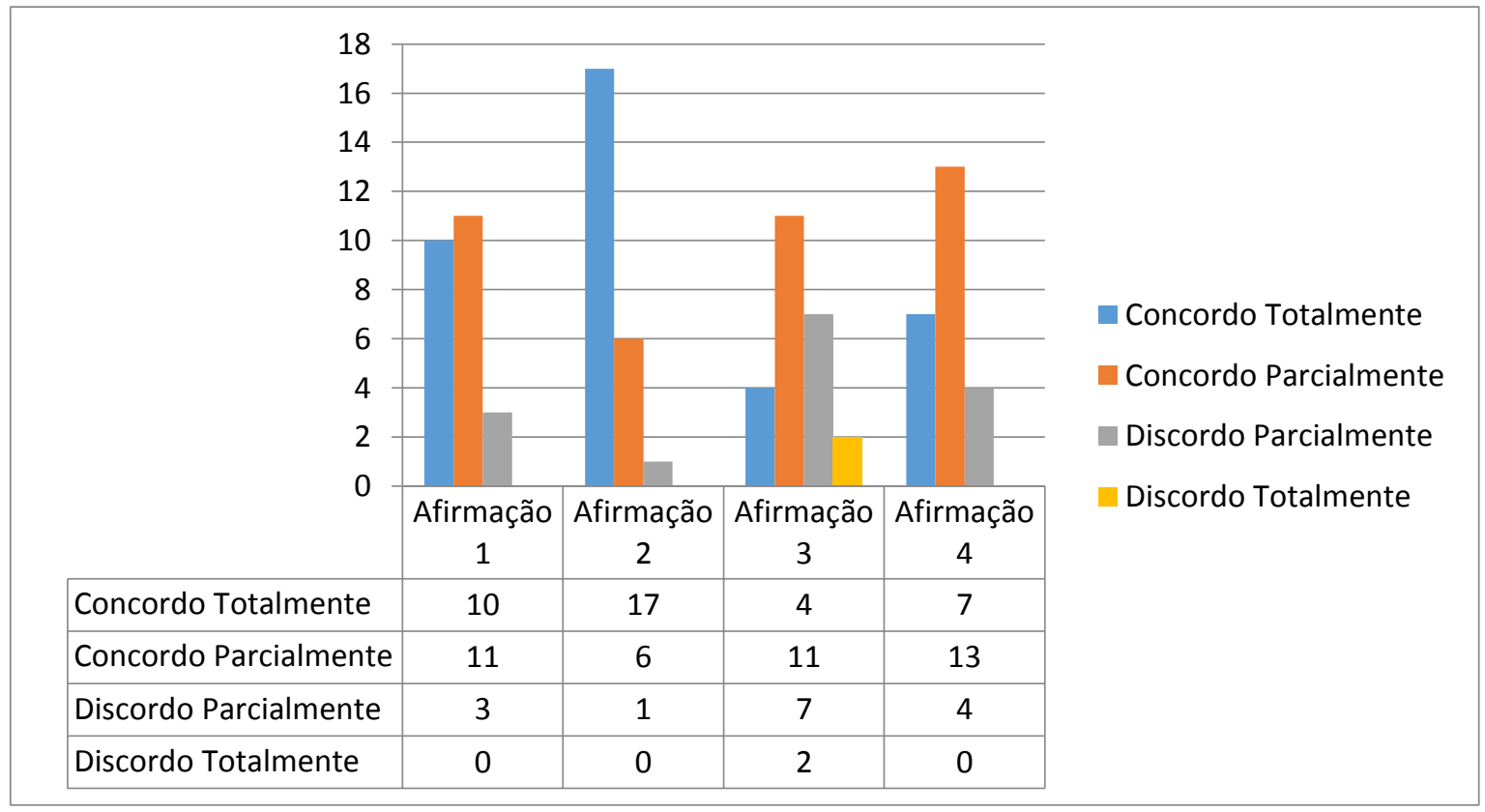

Fonte: Autor

Essa é a parte que mais gerou discordância em relação aos demais temas. Aqui já podemos ver que talvez a visão dos líderes acerca de Meritocracia não esteja adequada ao olhos dos colaboradores, visto que a maioria concorda parcialmente, representando em média $46 \%$ dos 
respondentes, 40\% concorda totalmente em média, 16\% discorda parcialmente em média e $1 \%$ discorda totalmente em média.

Esse já pode ser considerado um ponto de atenção aos gestores, principalmente se considerarmos que apenas na segunda afirmação deste tema os respondentes concordam totalmente em maioria. Nas demais perguntas, o que mais se observa são colaboradores concordando parcialmente.

Vale ressaltar que este é o único dos quatro temas que temos colaboradores discordando totalmente de alguma das afirmações e que onde mais se observa oscilação de respostas. 


\section{Conclusão}

Este trabalho teve como objetivo realizar uma análise crítica do modelo de gestão bancária moderna, tendo como amostra gestores e funcionários do Itaú Unibanco, visando identificar pontos fortes, pontos fracos e possíveis oportunidades de melhoria desta empresa para este assunto.

Com isso veio a necessidade de primeiro entender o que se entende de gestão atualmente, principalmente quando se trata do setor bancário, que se mostra cada vez mais desafiador e exigente ao passar dos anos. Bancos atualmente são reconhecidos por suas metas audaciosas, e lucros cada vez mais altos.

Mesmo nesse cenário, temos o Itaú Unibanco, como um dos que mais tem ativos em comparação com os demais, e ainda assim, se destaca como uma das melhores empresas para se trabalhar em órgãos reconhecidos como o GPTW (Great Place To Work).

Daí veio o objetivo deste estudo, que é entender o que o Itaú Unibanco faz de diferente que o coloca nessa posição de reconhecimento, visto todos os percalços que existem na área de atuação a qual pertence.

Baseado em conceitos de modelos de gestão, liderança e motivação, o autor propôs primeiramente buscar com os gestores que trabalham na data corrente no banco as principais características que fazem com que o Itaú Unibanco seja diferenciado para seus colaboradores. E nas dez perguntas que foram formuladas para estes líderes, 4 tópicos surgiram, que são: Liderança, Espírito de equipe, Motivação e Meritocracia.

Recorrentemente era observado que o foco dos gestores era 0 cuidado com pessoas, e como o indivíduo era valorizado em seu meio, gerando resultado com isso, exatamente como mostra as diversas outras empresas que se qualificam como boas para se trabalhar e de sucesso. 
Alguns chegavam a ressaltar seus métodos de liderança, que devem ser adaptados ao colaborador e suas ambições, e que esta liderança é reconhecida pelo exemplo.

Feito a entrevista com os gestores, formulou-se a segunda etapa do estudo, que foi um questionário com colaboradores de agências distintas com o intuito de validar justamente o que os gestores afirmavam. E o resultado foi como esperado em grande parte do que se foi levantado. Nos tópicos que tangem Liderança, Motivação e Espírito de equipe, houve na esmagadora maioria concordância com o que os gestores pregavam, apenas com ressalvas no que tange Meritocracia, onde por sua vez teve discordâncias maiores, apontando talvez um equívoco da visão dos líderes.

Em suma, a posição em que o Itaú Unibanco se encontra atualmente como uma das melhores empresas para se trabalhar não é em vão, visto que em grande parte seus gestores e demais colaboradores reconhecem isso através da gestão praticada dentro da empresa. Sendo assim, esse é seu ponto forte, tendo como ressalva a visão acerca de Meritocracia, devido a alguns colaboradores não a reconhecerem como os gestores pregam.

\subsection{Sugestões e recomendações para novos estudos}

Como sugestão, o principal ponto a ser melhorado que foi observado no estudo foi a percepção dos colaboradores acerca do que se entende por Meritocracia na empresa. Há então de se entender o que está falhando na gestão praticada que faz com que os funcionários não reconheçam esse tópico da mesma forma que reconhecem as lideranças, as motivações e o espírito de equipe em suas agências.

Como outra sugestão, pode-se acrescentar avaliar como o desenvolvimento de gestores se dá na organização, e como esse conhecimento é passado adiante, visto que estes são peça chave para controlar o ambiente bancário e torna-lo saudável para trabalhar. 


\section{Referências Bibliográficas}

BASS, B. M.; AVOLIO, B. J. Reexaminando os componentes da Liderança Transformacional e Transacional usando o questionário de Liderança Multifator. Journal of Occupational \& Organizational Psychology, v. 72, n. 4, 441-462, 1999.

Bradesco e Santander se destacam em crescimento de lucratividade no $3^{\circ}$ trimestre de 2018 entre bancos com mais de US\$ 100 bilhões em ativos. Sistema Economatica, 2018. Disponível em: <https://economatica.com/estudos/data/20181112a.pdf>. Acesso em: 03 dez. 2018.

CALAÇA, Pedro Alessandro; VIZEU, Fábio. Revisitando a perspectiva de James MacGregor Burns: qual é a ideia por trás do conceito de liderança transformacional?. 2013. 15 p. Dissertação (Doutorado em Administração de Empresas)- FGV, Rio de Janeiro, 2014. Disponível

em: <http://bibliotecadigital.fgv.br/ojs/index.php/cadernosebape/article/view/11 016/41259>. Acesso em: 27 set. 2018.

CHIAVENATO, Idalberto. Introdução à Teoria Geral da Administração. 8ª ed. Rio de Janeiro: Elsevier, 2011.

CUNHA, M. P.; REGO, A.; CUNHA, R. C.; CABRAL, C. Manual de comportamento organizacional e gestão. $5 \mathrm{a}$ ed.. Lisboa: RH Editora, 2004.

FALCONI, Vicente. Gerenciamento pelas diretrizes: (Hoshin Kanri) $O$ que todo membro da alta administração precisa saber para vencer os desafios do novo milênio. $5^{\mathrm{a}}$. ed. São Paulo: Falconi Editora, 2013.

Great Place To Work. Melhores empresas para trabalhar. Disponível em: $\quad$ https://gptw.com.br/ranking/melhoresempresas/?utm source=adwords\&utm medium=adwords\&utm campaign 
=melhores-empresas-para-trabalhar\&gclid=CjwKCAjwzenbBRB3EiwAltSu92rZ35vAghZowHiXpQSuouoKix vEmuKU3zIG5Jcg0BLMC2QBF6wxoC VpIQAvD BwE>. Acesso em: 15 de setembro de 2018.

ITAÚ UNIBANCO SA. Sobre o Itaú Unibanco. Disponível em:< https://www.itau.com.br/sobre/quem-somos/cultura-corporativa/ >. Acesso em:06 jul. 2017.

KINICKI, Angelo; KREITNER, Robert. Comportamento organizacional. São Paulo: McGraw-Hill, 2006.

MACIEL, Helltonn; COSTA, Marcia. Modernas práticas de gestão do setor bancário brasileiro. Outubro de 2014. Artigo (Seminário de administração) - Universidade Federal da Paraíba, João Pessoa, 2014.

PERIARD, Gustavo. Meritocracia nas empresas. 2011. Disponível em: <http://www.sobreadministracao.com/meritocracia-nas-empresas/>. Acesso em: 27 set. 2018.

ROBBINS, S. P. Comportamento organizacional. 11. ed. São Paulo: Pearson, 2005.

SOBRAL, F; PECl, A. Administração: teoria e prática no contexto brasileiro. São Paulo: Pearson, 2013.

ZUINI, Priscila. 10 pequenas empresas que são exemplo de gestão e competitividade: Dez empresas foram reconhecidas por boas práticas de gestão no Prêmio MPE Brasil. 2016. Disponível em: $<$ https://revistapegn.globo.com/Empreendedorismo/noticia/2016/04/premio -mpe-brasil-anuncia-vencedores.html>. Acesso em: 27 set. 2018. 


\section{Anexos}

\subsection{Formulário entrevista com gestores}

1- Qual sua principal tarefa como gestor e figura de liderança? (Referenciais: Modelo atual de empresa de sucesso e Liderança)

2- Como você se avalia nessa posição? (Referenciais: Traços culturais da administração brasileira e Liderança)

3- Sua equipe percebe e participa de sua gestão? (Referenciais: Cultura organizacional, Liderança, Motivação Humana e Modelo atual de empresa de sucesso)

4- Como você reconhece a motivação de sua equipe? (Referencial: Motivação Humana)

5- Para você, seu papel de líder é fundamental para a motivação da equipe? (Referenciais: Liderança, Motivação Humana)

6- Quais são os principais traços de liderança que você observa no banco? Dentre esses qual você mais se identifica? (Referenciais: Administração no Brasil, Liderança)

7- Acredita que no Itaú Unibanco, o reconhecimento dos funcionários é meritocrático ou paternalista? (Referenciais: Administração no Brasil, Cultura organizacional, Meritocracia)

8- O banco permite que as necessidades de seus funcionários sejam levados em conta? (Referenciais: Cultura organizacional, Motivação Humana)

9- Como você trata os conflitos de interesse dentro da sua equipe? (Referenciais: Administração no Brasil, Liderança, Modelo atual de empresa de sucesso)

10- Qual o maior desafio de um gestor? (Referenciais: Administração no Brasil, Liderança) 


\subsection{Formulário entrevista com colaboradores}

Avaliação do modelo de gestão praticada no Itaú Unibanco

Página 1

Frezados, neste formulario busca-se ievantar as susa percepçbes como colsborador do tas. Unbanco acerca de seus lideres direlos e a geatio praticada pelos meamos.

Serdo felisa afmaçles com o intulto de enplorar quatro aspectos inerentes a gestbo de pessoss: Luderança, Motvaçlo, Eapirtto de equipe e Merhocracis.

Reapondam se concordam ou nfo com ezsas afmmaçbes tendo em mente sua gestibo dreta dentro do banco, de forma sincera e justa.

\section{Afirmações acerca da Liderança}

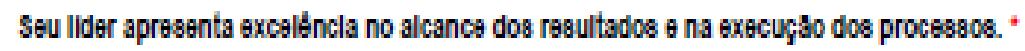
Dlecordo bsosimente
Decordo parclaments
concordo partisimente
concordo totaments

Na sua agencla, s9u gestor IIdera pelo o exemplo. *

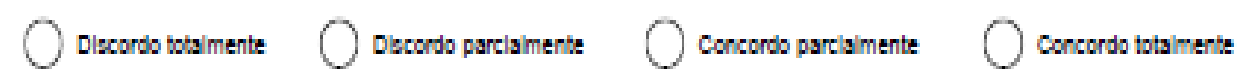

Seu gestor preza pelo encarreliramento das pessoss. .

olecordso bsasmente $\bigcirc$ obcordo parclaments $\bigcirc$ concorso parcismente $\bigcirc$ concordo totaments

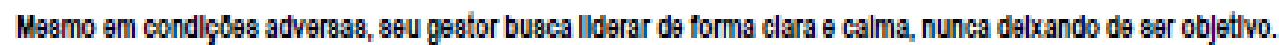
$+$

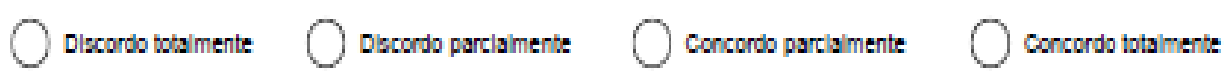

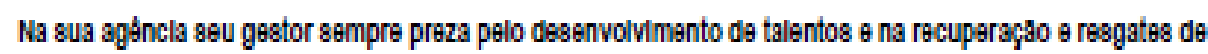
pessoss com balxo rendlmento. *

Dlecordso bsasmente $\bigcirc$ Diccordo parclaments $\bigcirc$ concorso parcismente $\bigcirc$ concordo totaments 
Em sua agincla seu gestor busca mostrar os erros como forma de aprendlzado. *

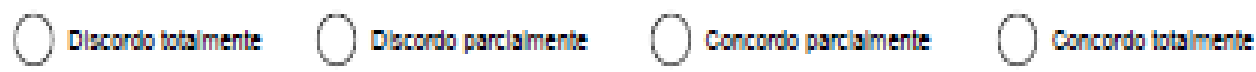

Afirmaçón acerca da Motivaça

Seu gastor no banco se preocupa con a sua mothapho peseas. *

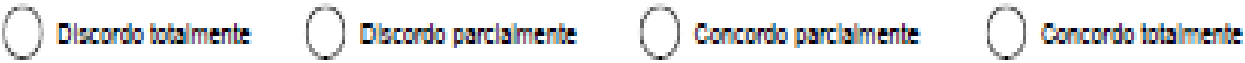

Wock sempre as aente confortavel para dlalogar com seu gator. *

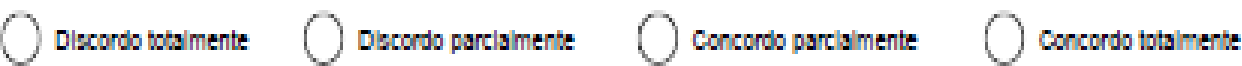

Na equlpa agu gestor gera eapşo para suas necesaldades 6 as dos demals allnharen-se con o reaultado da agencla."

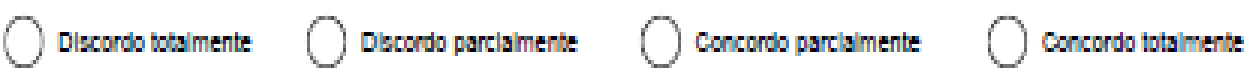

Afirmaçōes acerca do Espírito em equipe

Mau gestor Incentwa o dlalogo entre a equ|pe nåo Importa o cllma da agdncla. *

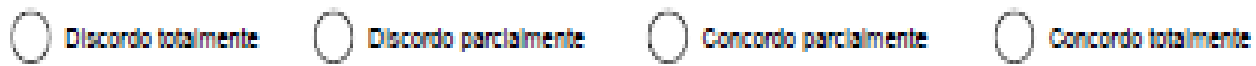

Vock se sente a wontade para particlpar das declases da equlpe e do gestor. ${ }^{+}$

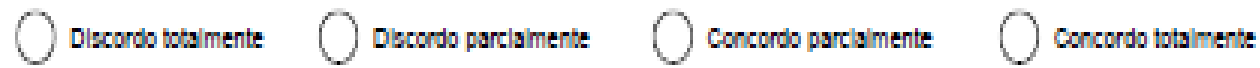

Seu gastor sabe ldentificar sempre quando ha falta de sintonla na equlpe."

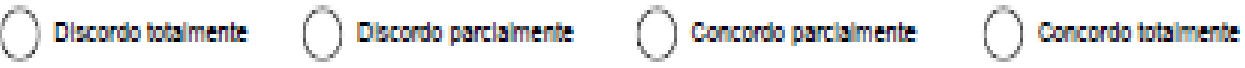


0 gestor de sua equlpe abe gerlr conflltos a atendar a todos democratcamente. "

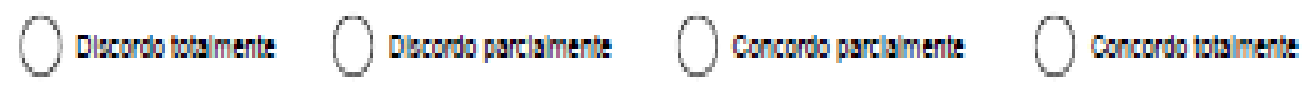

Afirmaçōes acerca da Meritocracia

Os funclunârios acrodltam que todos sao reconhacidos pelo seu ampenho."

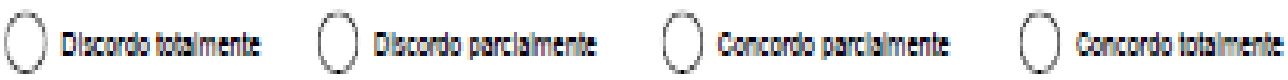

Wa sua equlpe seu gestor reconheca talsntos a Incentwa a axcelincla."

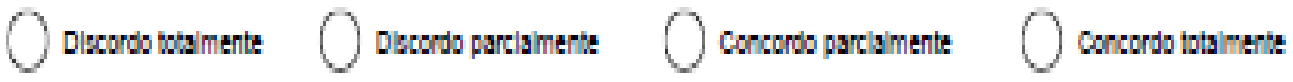

Paternallano e algo que naso acontece en nenhum momento no banco. *

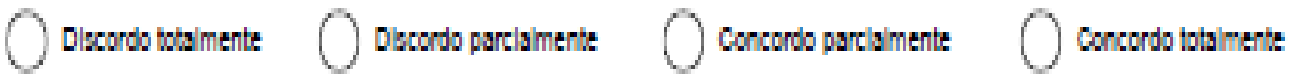

Wod sente que o banco, atraves de seu gegto, permilte o encarralranento reconheclmento de aeus funclonárlos da forma mertocratlca sempre. ${ }^{*}$

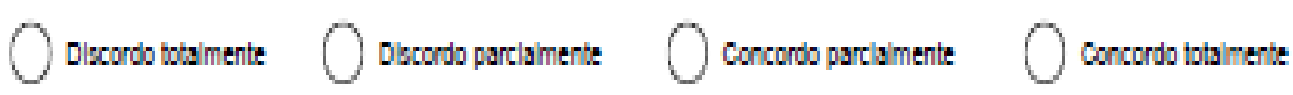

